\title{
ANALISIS KESESUAIAN BUKU TEKS MATEMATIKA KELAS VII DENGAN KOMPETENSI INTI DAN KOMPETENSI DASAR KURIKULUM 2013
}

\author{
Sanianajiba Nugroho Putri \\ LAIN Salatiga, Indonesia \\ E-mail: sanianajiba42@gmail.com
}

\begin{abstract}
This study aims to describe the level of conformity between Class VII Mathematics Textbooks with Core Competencies and Basic Competencies of Curriculum 2013. Starting from the suitability of Basic Competencies from Core Competencies 1, Core Competencies 2, Core Competencies 3, and Core Competencies 4. The research method used is qualitative descriptive approach The primary data source used is the Mathematics Textbook for Class VII Semester 2 Revised 2017 Edition published by the Ministry of Education and Culture. While the secondary data sources are journals and relevant previous research results. The data collection used is a document content analysis (content analysis). To check the validity of this research data by increasing persistence. This descriptive research is intended to describe and analyze the level of conformity of the book with the Core Competencies and Basic Competencies. The results of this study, the level of conformity of the Mathematics Textbook for Class VII Semester 2 Revised 2017 Edition with the Implementation of Core Competencies and Basic Competencies of the 2013 Curriculum obtained a score of $86.5 \%$ in the "very good" category. The level of conformity of Basic Competency 1 from Core Competency 1 is $60 \%$ (Good Enough). The level of conformity of Basic Competency 2 from Core Competency 2 is 100\% (Very Good). The level of conformity of Basic Competency 3 from Core Competency 3 is 93\% (Very Good). The level of conformity of Basic Competency 4 from Core Competency 4 is 93\% (Very Good).
\end{abstract}

Keywords: Analysis, Textbooks, Mathematics, Core Competencies, Basic Competencies, Curriculum 2013

\begin{abstract}
Abstrak
Penelitian ini bertujuan untuk mendeskripsikan tingkat kesesuaian antara Buku Teks Matematika Kelas VII dengan Kompetensi Inti dan Kompetensi Dasar Kurikulum 2013. Mulai dari Kesesuaian Kompetensi Dasar dari Kompetensi Inti 1, Kompetensi Inti 2, Kompetensi Inti 3, dan Kompetensi Inti 4. Metode penelitian yang digunakan adalah pendekatan deskriptif kualitatif Sumber data Primer yang digunakan adalah Buku Teks Matematika Kelas VII Semester 2 Edisi Revisi 2017 yang diterbitkan oleh Kemendikbud. Sedangkan sumber data sekunder yaitu jurnal serta hasil penelitian terdahulu yang relevan. Pengumpulan data yang digunakan adalah pengkajian isi dokumen (analysis content). Untuk mengecek keabsahan data penelitian ini dengan meningkatkan ketekunan. Penelitian deskriptif ini dimaksudkan untuk mendeskripsikan dan menganalisis tingkat kesesuaian buku dengan Kompetensi Inti dan Kompetensi Dasar. Hasil dari penelitian ini tingkat kesesuaian Buku Teks Matematika Kelas VII Semester 2 Edisi Revisi 2017 dengan Implementasi Kompetensi Inti dan Kompetensi Dasar Kurikulum 2013 memperoleh skor 86,5\% kategori "sangat baik". Tingkat kesesuaian Kompetensi Dasar 1 dari Kompetensi Inti 1 adalah 60\% (Cukup Baik). Tingkat kesesuaian Kompetensi Dasar 2 dari Kompetensi Inti 2 adalah 100\% (Sangat Baik). Tingkat kesesuaian Kompetensi Dasar 3 dari Kompetensi Inti 3 adalah 93\% (Sangat Baik). Tingkat kesesuaian Kompetensi Dasar 4 dari Kompetensi Inti 4 adalah 93\% (Sangat Baik).
\end{abstract}

Kata Kunci: Analisis, Buku Teks, Matematika, Kompetensi Inti, Kompetensi Dasar, Kurikulum 2013 


\section{Pendahuluan}

Segala sesuatu yang dilakukan pasti memiliki tujuan, begitu pula dengan Pendidikan. Pendidikan pada umumnya dilakukan untuk membuat perubahan ke arah yang lebih baik lagi. Baik itu dari segi kognitif maupun segi attitude (perilaku). Sementara tujuan pendidikan nasional sudah dirumuskan dalam undang-undang.

Sebelum membahas tentang tujuan Pendidikan Nasional. Akan dibahas definisi Pendidikan terlebih dahulu. Definisi tentang Pendidikan diatur dalam Undang - Undang Nomor 20 Tahun 2003 tentang Sistem Pendidikan Nasional Bab I Pasal 1 Ayat 1 yang berbunyi Pendidikan adalah usaha sadar dan terencana untuk mewujudkan suasana belajar dan proses pembelajaran agar peserta didik secara aktif mengembangkan potensi dirinya untuk memiliki kekuatan spiritual keagamaan, pengendalian diri, kepribadian, kecerdasan, akhlak mulia, serta keterampilan yang diperlukan dirinya, masyarakat, bangsa dan negara.

Menimbang betapa pentingnya peran pendidikan dalam kehidupan suatu bangsa dan Negara, Pemerintah sudah mengajak segenap komponen bangsa mengupayakan terwujudnya pendidikan yang berkualitas. Dalam menjamin mutu pendidikan adalah tugas dan tanggung jawab bersama antara pemerintah, masyarakat, dan pelaku pendidikan.

Pendidikan berguna agar mendapatkan Ilmu yang berguna untuk kehidupan di dunia dan akhirat. Dalam Islam dijelaskan betapa pentingnya Ilmu. Pada Hadis Riwayat Abu Dawud dan AtTarmidzi disebutkan bahwa Ilmu lebih berharga dibandingkan dengan uang. Bunyi dari Hadisnya sebagai berikut :

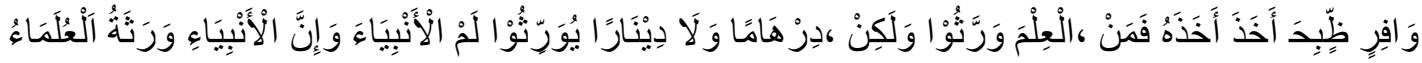

Artinya :

"Para ulama adalah pewaris para Nabi. Sesungguhnya para Nabi tidak mewariskan dinar ataupun dirham, tetapi mewariskan ilmu. Maka dari itu, barang siapa mengambilnya, ia telah mengambil bagian yang cukup." (HR. Abu Dawud, at-Tirmidzi, dan Ibnu Majjah; dinyatakan shahih oleh asy-Syaikh al-Albani dalam Shabibul Jami' no.6297)

Tujuan pendidikan nasional sebagaimana tercantum dalam Undang - Undang Nomor 20 Tahun 2003 Pasal 3 menegaskan bahwa Pendidikan nasional berfungsi mengembangkan kemampuan dan membentuk watak serta peradaban bangsa yang bermartabat dalam rangka mencerdaskan kehidupan bangsa, bertujuan untuk mengembangkan potensi peserta didik agar menjadi manusia yang beriman dan bertakwa kepada Tuhan Yang Maha Esa, berakhlak mulia, sehat, berilmu, cakap, kreatif, mandiri, dan menjadi warga Negara yang demokratis serta bertanggung jawab.

Untuk mewujudkan tujuan pendidikan nasional tersebut, pemerintah Republik Indonesia melalui Kementerian Pendidikan dan Kebudayaan telah melakukan inovasi berupa evaluasi dan pembaharuan Kurikulum (Ramda, 2017, 13).

Kurikulum merupakan seperangkat alat yang dijadikan pedoman dalam penyelenggaraan pendidikan. Kurikulum sebagai rencana pembelajaran adalah sebuah rencana pembelajaran di suatu sekolah. Kurikulum adalah sejumlah mata pelajaran yang harus ditempuh atau dipelajari siswa di sekolah atau perguruan tinggi untuk memperoleh ijazah tertentu (Tafsir, 2006 : 53). Definisi serupa juga dijabarkan dalam Undang-Undang Nomor 20 Tahun 2003 tentang Sistem Pendidikan Nasional Bab I Pasal 1 Ayat 19 menyatakan "Kurikulum adalah seperangkat rencana dan pengaturan mengenai tujuan, isi, dan bahan pelajaran serta cara yang digunakan sebagai pedoman penyelenggaraan kegiatan pembelajaran untuk mencapai tujuan pendidikan nasional.” Kurikulum 
bersifat dinamis, artinya dapat berubah-ubah disesuaikan dengan perkembangan dan kebutuhan zaman.

Di Indonesia, telah terjadi beberapa kali perkembangan kurikulum, mulai dari kurikulum 1968, Kurikulum 1975, Kurikulum 1984, Kurikulum 1994, Kurikulum Berbasis Kompetensi (KBK), Kurikulum Tingkat Satuan Pendidikan (KTSP), dan yang terakhir Kurikulum 2013 (Unam, 2017: 2). Kurikulum 2013 dikembangkan untuk mempersiapkan manusia Indonesia agar memiliki kemampuan hidup sebagai pribadi dan warga Negara yang beriman, produktif, kreatif, inovatif dan afektif serta mampu berkontribusi kepada kehidupan bermasyarakat, berbangsa dan bernegara serta peradaban dunia (Permendikbud No. 68).

Untuk menjamin tercapainya tujuan pendidikan tersebut, Pemerintah menetapkan Peraturan Pemerintah Nomor 32 Tahun 2013 pengganti PP Nomor 19 Tahun 2005 tentang Standar Nasional Pendidikan (SNP). Secara garis besar, PP tersebut mengatur standar pendidikan yang meliputi standar isi, standar proses, standar kompetensi lulusan, standar pendidik dan tenaga kependidikan, standar sarana dan prasarana, standar pengelolaan, standar pembiayaan, dan standar penilaian pendidikan. Buku teks pelajaran adalah salah satu unsur dalam standar sarana dan prasarana. Selain itu, buku teks pelajaran merupakan salah satu kebutuhan utama dalam pembelajaran menurut Mesa\&Griffiths (dalam Ramda, 2017: 13).

Menurut Nasin \& Anno (dalam Yusmium, 2015: 3) Pada Kurikulum 2013, penataan sistem perbukuan ditangani langsung oleh pemerintah. Hal ini menjadi salah satu perbedaan antara Kurikulum 2013 dengan Kurikulum Tingkat Satuan (KTSP). Buku teks pelajaran merupakan alat bantu yang digunakan oleh guru dan siswa dalam pembelajaran. Peran buku teks dalam proses pembelajaran masih dianggap penting hingga pemerintah dalam hal ini Menteri Pendidikan Nasional mengeluarkan Peraturan Menteri khusus tentang buku teks pelajaran, yaitu Permendikbud Nomor 71 Tahun 2013 tentang Buku Teks Pelajaran dan Buku Panduan Guru untuk Pendidikan Dasar Dan Menengah.

Menurut Shield \& Dole (dalam Ramda, 2017: 13) dalam pelajaran matematika, buku teks pelajaran dapat membantu peserta didik dalam membangun pemahamannya terhadap matematika dan merepresentasikan matematika tersebut. Oleh karena itu, Buku teks pelajaran Matematika hendaknya mendukung pencapaian kompetensi-kompetensi yang harus dikuasai oleh peserta didik sesuai dengan tingkat kelasnya (Ramda, 2017 : 13).

Buku teks pelajaran yang mengacu pada Kurikulum 2013 hendaknya memenuhi Standar Pendidikan yang sesuai dengan ketentuan dalam penerapan Kurikulum 2013. Ketentuannya meliputi standar isi, standar proses, dan standar kompetensi lulusan. Standar Kompetensi Lulusan adalah kriteria mengenai kualifikasi kemampuan lulusan yang mencakup sikap, pengetahuan, dan keterampilan peserta didik yang harus dipenuhinya atau dicapainya dari suatu satuan pendidikan pada jenjang pendidikan dasar dan menengah. Standar Kompetensi Lulusan digunakan sebagai acuan untuk menetapkan kompetensi yang bersifat generik pada tiap Tingkat Kompetensi.

Kompetensi yang bersifat generik mencakup 3 (tiga) ranah yakni sikap, pengetahuan dan ketrampilan. Ranah sikap dipilah menjadi sikap spiritual dan sikap sosial. Dengan demikian, Kompetensi yang bersifat generik terdiri atas 4 (empat) dimensi yang mempresentasikan sikap spiritual, sikap sosial, pengetahuan, dan ketrampilan, yang disebut Kompetensi Inti (KI). Kompetensi yang bersifat generik atau Kompetensi Inti ini kemudian digunakan untuk menentukan kompetensi yang bersifat spesifik untuk tiap mata pelajaran. Selanjutnya, Kompetensi 
dan ruang lingkup materi digunakan untuk menentukan Kompetensi Dasar pada pengembangan kurikulum tingkat satuan dan jenjang pendidikan.

Meski sistem perbukuan buku teks pelajaran pada Kurikulum 2013 langsung ditangani oleh Pemerintah tetapi tidak menutup kemungkinan apabila terjadi kesalahan dalam penyusunan buku teks pelajaran. Pada hasil penelitian terdahulu, telah ditemukan beberapa ketidaksesuaian pada beberapa buku teks kurikulum 2013. Contohnya dipaparkan oleh Yusmium $(2015$, 4) yaitu pada mata pelajaran Sejarah Kebudayaan Islam kelas VII MTs juga ditemukan kesalahan, diantaranya pada halaman 25 tertulis "Allah Saw"(Kementrian Agama, 2014: 25) yang seharusnya "Allah Swt". Pada halaman 11 disebutkan, istri Nabi Ibrahim adalah Siti Hawa (Kementrian Agama, 2014: 11) padahal yang benar adalah Siti Hajar. Demikian juga pada Kedaulatan Rakyat online ditulis tentang kesalahan buku Bahasa Indonesia kelas VII pada cerita 'Gerhana' terdapat ungkapan kata-kata kasar yang jauh dari nilai karakter yang positif jelas Ruwanto (dalam Yusmium, 2015 : 4). Hasil analisis dari salah satu guru IPA MTs Safinatul Huda Kedung, Hanik Suliswati, S. Pd. yang menyatakan pada bab 1 buku guru IPA SMP kelas VII Kurikulum 2013 tidak terdapat isi Kompetensi Inti (KI)-1 yang menuntut adanya beberapa tindak lanjut bagi guru untuk menyiapkan sendiri.

Untuk mengurangi kesalahan dan kekeliruan yang mungkin terjadi sebaiknya diadakan Analisis buku kurikulum 2013 khususnya Buku Siswa. Analisis buku kurikulum 2013 merupakan kegiatan yang penting untuk memberikan masukan bagi kemungkinan revisi untuk penerbitan buku yang diterbitkan oleh kemendikbud. Dalam kegiatan analisis buku ini juga memberikan informasi dan pertimbangan bagi guru agar dalam melaksanakan pembelajaran lebih kreatif dan inovatif.

Dalam penelitian ini, peneliti bermaksud menganalisis implementasi empat Kompetensi Inti dan Kompetensi Dasar pada buku teks pelajaran Matematika Edisi Revisi 2017 Kemendikbud kelas VII semester 2. Sebagai temuan awal yang melatarbelakangi ketertarikan penulis dalam meneliti masalah ini adalah karena dari empat dimensi Kompetensi Inti yang ditetapkan yaitu KI-1 (Spiritual), KI-2 (Sosial), KI-3 (pengetahuan) dan KI-4 (Ketrampilan), ternyata penulis baru menemukan KI-3 dan KI-4 dalam buku teks pelajaran Matematika Edisi Revisi 2017 Kemendikbud kelas VII semester 2. Artinya, peneliti belum menemukan adanya muatan KI-1 dan KI-2 dalam buku teks tersebut. Inilah yang akan menjadi pokok bahasan dalam penelitian ini. Sehingga Peneliti mengangkat Judul Penelitian “ Analisis Kesesuaian Isi Buku Teks Mata Pelajaran Matematika SMP/MTs Kelas VII Semester 2 Dengan Kompetensi Inti Dan Kompetensi Dasar Kurikulum 2013 (Studi Analisis Pada Buku Kemendikbud Edisi Revisi 2017)”

\section{METODE}

Penelitian ini menggunakan pendekatan kualitatif. Peneliti menggunakan penelitian ini dikarenakan penelitian dilakukan pada obyek yang alamiah atau berkembang apa adanya. Pendekatan Kualitatif juga digunakan untuk mendapatkan data yang mendalam, suatu data yang mengandung makna. Makna adalah data yang sebenarnya, data yang pasti yang merupakan suatu nilai dibalik data yang tampak. Metode penelitian kualitatif adalah metode penelitian yang berlandaskan pada filsafat postpositivisme, digunakan untuk meneliti pada kondisi obyek yang alamiah, (sebagai lawannya adalah eksperimen) dimana peneliti adalah sebagai instrumen kunci, teknik pengumpulan data dilakukan secara triangulasi (gabungan), analisis data bersifat induktif/kualitatif, dan hasil penelitian kualitatif lebih menekankan makna dari pada generalisai (Sugiyono, 2016: 9). Lebih spesifiknya lagi penelitian ini menggunakan Pendekatan deskriptif 
kualitatif karena dalam penelitian ini peneliti akan menganalisis, mendeskripsikan, menjelaskan, memaparkan, menuliskan, serta melaporkan keadaan objek atau data yang diperoleh dari sumber data. Pengumpulan data dilakukan pada bulan Mei sampai Juni 2020.

Sumber data yang digunakan pada penelitian ini ada dua yaitu sumber primer dan sumber sekunder. Sumber primer yang digunakan dalam penelitian ini berupa buku mata pelajaran Matematika kelas VII Semester 2 edisi revisi 2017 yang diterbitkan oleh Kementrian Pendidikan dan Kebudayaan. Sedangkan untuk sumber sekundernya adalah hasil penelitian berjudul Analisis Buku Siswa Matematika Kurikulum 2013 untuk. Kelas X Berdasarkan Rumusan Kurikulum 2013 karya Maulana Syamsu Widyaharti (Mahasiswa S-1 Program Studi Pendidikan Matematika FKIP Universitas Jember), Dinawati Trapsilasiwi (Dosen Prodi Pendidikan Matematika FKIP Universitas Jember), dan Arif Fatahilah (Dosen Prodi Pendidikan Matematika FKIP Universitas Jember), hasil penelitian Analisis Kesesuaian Materipada Buku Teks Matematika Kelas VII dengan Kurikulum 2013 karya Apolonia Hendrice Ramda Mahasiswa STIKP St. Paulus Ruteng dalam Phythagoras : Jurnal Pendidikan Matematika, 12(1), 2017, 12-22, dan hasil penelitian berjudul Analisis Buku Matematika Siswa SMP Kurikulum 2013 karya Ilham Rizkianto (Departemen Pendidikan Matematika, Universitas Negeri Yogyakarta) dan Rusgianto Heri Santosa (Departemen Pendidikan Matematika, Universitas Negeri Yogyakarta) dalam Jurnal "Mosharafa", Volume 6, Nomor 2, Mei 2017.

Prosedur pengumpulan data atau teknik pengumpulan adalah salah satu langkah yang penting dalam penyusunan penelitian. Teknik pengumpulan data merupakan langkah yang paling strategis dalam penelitian, karena tujuan utama dari penelitian adalah mendapat data (Sugiyono, $2016: 224$ ). Teknik pengumpulan data yang digunakan adalah dengan dokumen. Menurut Sugiyono (2016: 240) menyatakan bahwa dokumen merupakan catatan peristiwa yang sudah berlalu. Ia juga menyatakan bahwa dokumen bisa berbentuk tulisan, gambar, atau karya-karya monumental dari seseorang. Dalam penelitian ini memilih buku Siswa Mata Pelajaran Matematika SMP/MTs kelas VII semester 2 Kurikulum 2013 edisi revisi 2017 untuk ditelaah sebagai bahan dokumen dalam pengumpulan data. Metode dokumentasi dalam penelitian ini digunakan agar peneliti dapat mendapatkan data persentase skor pada masing-masing sub aspek yang diteliti.

Sebelumnya sudah dijelaskan bahwa Penelitian ini menggunakan Pendekatan deskriptif kualitatif sehingga peneliti mendeskripsikan, mencatat, menganalisis, dan menginterpretasikan keadaan-keadaan yang ada dalam bahasa verbal dalam buku Siswa Mata Pelajaran Matematika kurikulum 2013 SMP/MTs kelas VII semester 2 edisi revisi 2017 dengan Kompetensi Inti dan Kompetensi Dasar yang ada. Dalam penelitian ini peneliti menjadi instrumen atau alat penelitian itu sendiri. Peneliti berperan untuk melakukan semua proses dalam penelitian mulai dari membaca buku teks siswa, mendeskripsikan, mencatat, menganalisis, dan menginterpretasikan keadaankeadaan yang ada.

Teknik analisis data pada penelitian ini adalah penelitian isi (content analysis) dengan menggunakan studi dokumentasi seperti Buku Siswa Matematika kurikulum 2013 kelas VII SMP/MTs edisi revisi 2017, Kurikulum, KI dan KD. Sebagaimana dijelaskan Arikunto (2013: 92) bahwa analisis dokumen istilah lainnya adalah analisis isi, analisis aktifitas atau analisis informasi contoh kegiatannya adalah meneliti dokumen, menganalisa peraturan, hukum dan keputusan keputusan. Dari pembahasan di atas dapat disimpulkan bahwa penelitian ini termasuk analisis dokumenter atau analisis isi, karena terdiri dari prosedur untuk menarik kesimpulan dari dokumen yaitu buku Siswa Matematika SMP/MTs kurikulum 2013 edisi revisi 2017 apakah buku tersebut sudah sesuai dengan Kompetensi Inti dan Kompetensi Dasar yang ada. 
Alur analisis deskriptif yang pertama tama dimulai dari menentukan obyek penelitian yang dijadikan sumber primer penelitian ini. Dari obyek penelitian difokuskan empat aspek yang akan dianalisis yang hasilnya menggambarkan kesesuaian buku.

Instrumen penelitian ini memiliki 3 tingkat pilihan jawaban yaitu "terpenuhi”, "terpenuhi sebagian" dan "tidak terpenuhi". Pilihan ini berdasarkan Instrumen analisis buku yang didapat dari hasil sosialisasi Kurikulum 2013 dari Kementrian Pendidikan dan Kebudayaan. Setiap pilihan jawaban memiliki skor yang berbeda-beda tergantung tingkat kesesuaiannya. Pilihan "terpenuhi", diberi skor 5, pilihan "terpenuhi sebagian" diberi skor 3, dan pilihan "tidak terpenuhi" diberi skor 1. Penilaian instrumen total diperoleh dari skor yang didapat kemudian dibagi dengan skor maksimal kemudian hasilnya dikali dengan 100. Skor penilaian dari tiap pilihan jawaban ini dapat dilihat dalam Tabel 1.

Tabel 1. Skor Penilaian terhadap pilihan jawaban

\begin{tabular}{|c|c|}
\hline Pilihan Jawaban & Skor \\
\hline Terpenuhi & 5 \\
\hline $\begin{array}{c}\text { Terpenuhi } \\
\text { sebagian }\end{array}$ & 3 \\
\hline Tidak terpenuhi & 1 \\
\hline
\end{tabular}

Instrumen yang digunakan memiliki 3 pilihan jawaban, sehingga skor penilaian total dapat dicari dengan menggunakan rumus :

Persentase Kesesuaian $=\frac{\text { Skor Jawaban }}{\text { Skor Maksimal }} \times 100 \%$

Berikut akan ditampilkan Kategori Hasil Penilaian pada tabel 2 berdasarkan persentase kesesuaian yang sudah diperoleh :

Tabel 2. Kategori Hasil Penilaian

\begin{tabular}{|c|c|}
\hline Persentase & Status Kesesuaian \\
\hline $85-100$ & Sangat Baik \\
\hline $65-84$ & Baik \\
\hline $55-64$ & Cukup Baik \\
\hline $40-54$ & Kurang Baik \\
\hline $20-39$ & Tidak Baik \\
\hline
\end{tabular}

Pengecekan Keabsahan Data

Untuk mengecek keabsahan data temuan penelitian atau sering disebut dengan reduksi data pada penelitian ini adalah dengan meningkat ketekunan. Menurut Sugiyono (2016: 272) menyatakan bahwa meningkatkan ketekunan berarti melakukan pengamatan secara lebih cermat dan berkesinambungan. Dengan cara tersebut maka data yang diperoleh akan lebih pasti dan sistematis. Dalam pengecekan keabsahan data menggunakan teknik meningkatkan ketekunan, peneliti melakukan pengamatan dengan cermat, tekun, teliti dan mendalam pada materi buku ajar yang diteliti untuk memusatkan diri pada latar penelitian, untuk memperoleh data dan unsur-unsur yang relevan dengan persoalan yang diteliti.

\section{HASIL DAN PEMBAHASAN}


Pada hasil pembahasan ini didapatkan beberapa data mengenai tingkat kesesuaian buku teks pelajaran Matematika kelas VII semester 2 dengan implementasi KI dan KD kurikulum 2013. Pertama-tama yang akan dibahas adalah KI dan KD 1 tentang sikap spiritual. Kompetensi Inti 1 terdiri dari satu Kompetensi Dasar yang memiliki uraian yang sama yaitu "Menghargai dan menghayati ajaran agama yang dianutnya" Setelah peneliti menganalisis implementasi Kompetensi Inti dan Kompetensi Dasar 1 ternyata hanya pada Bab 5 (Perbandingan) yang sudah memenuhi KI dan KD 1. Hal ini terlihat dari Bab 5 yang menyinggung tentang bukti-bukti kehebatan Tuhan melalui perbandingan Ilahi (Perbandingan emas). Berbeda dengan Bab 5 pada Bab 8 (Segiempat dan Segitiga) justru belum terlihat adanya tanda-tanda yang akan membuat peserta didik menghargai dan menghayati ajaran agama yang dianut.

Sedangkan pada Bab 6 (Aritmetika Sosial), Bab 7 (Garis dan Sudut), dan Bab 9 (Penyajian Data) sudah memenuhi sebagian dari implementasi Kompetensi Inti dan Kompetensi Dasar 1. Pada bab 6 halaman 66 dijelaskan tentang hikmah dari kehidupan David Ricardo yaitu "Ilmu yang kita miliki sebaiknya kita gunakan untuk hal kebaikan" dan "Dengan terus berfikir dan nularkan ilmu kita memberikan manfaat yang bisa dirasakan oleh orang banyak" dari situ terlihat bahwa ajaran agama terselip disana. Dengan disisipkannya ajaran agama ini memungkinkan membuat peserta didik menjadi menghargai dan juga menghayati Ajaran Agama yang dianutnya. Dapat disimpulkan bahwa Bab 6 ini sudah mencantumakan ajaran Agama meskipun hanya dijelaskan sedikit pada awal-awal saja. Pada Bab 7 ( Garis dan sudut) ini terlihat ada beberapa kalimat yang mencerminkan ajaran agama. Kalimat tersebut ada pada halaman 104 yang bertuliskan Kita harus mampu berbagi ilmu pengetahuan kepada siapa saja tanpa pandang status sosial, sehingga ilmu yang kita miliki akan bermanfaat untuk orang lain. Selain pada paragraph diatas terdapat pula kata-kata lagi yang akan membuat peserta didik menghayati ajaran agama. Kata-katanya yaitu "Kita ini termasuk manusia yang lemah, tapi berakal. Jika kita tidak menggunakan akal pikiran kita semaksimal mungkin, maka tidak ada bedanya dengan hewan. Maka dari itu gunakanlah akal pikiran kita untuk berbuat sesuatu yang bermanfaat dengan mengikuti prinsip-prinsip manusiawi. Apabila kita mempunyai ilmu ajarkanlah kepada orang lain, niscaya ilmu kita akan bertambah". Kalimat yang terakhir sering kita dengar sesuai dengan ajaran Agama Islam yaitu ketika kita memberi justru akan bertambah. Pada Bab 9 halaman 302 dijelaskan mengenai Hikmah yang dapat diambil dari sosok Karl Pearson yaitu salah satunya adalah tertulis disana Orang yang baik adalah orang yang bermanfaat dan memberikan kontribusi positif dalam bentuk apapun kepada orang lain. Hal ini seperti Hadits Rasulullah yang berbunyi "Sebaik-baiknya manusia adalah yang paling baik akhlaknya". Dari penjelasan itu meskipun hanya sedikit tetapi Bab 9 sudah menunjukkan tentang sikap menghayati ajaran agama.

Setelah membahas tentang Kompetensi Inti dan Kompetensi Dasar 1. Pada paragraf ini akan menjelaskan tentang Kompetensi Inti 2. Dalam Kompetensi Inti 2 terdiri dari 3 Kompetensi Dasar. Kompetensi Inti 2 sendiri berbunyi "Menghargai dan menghayati perilaku jujur, disiplin, tanggung jawab, peduli (toleransi, gotong royong), santun, percaya diri, dalam berinteraksi secara efektif dengan lingkungan sosial dan alam dalam jangkauan pergaulan dan keberadaannya". Sedangkan Kompetensi Dasarnya ada 3 yaitu KD 2.1 "Menunjukkan sikap logis, kritis, analitik, konsisten dan teliti, bertanggung jawab, responsif, dan tidak mudah menyerah, dalam memecahkan masalah", KD 2.2 "Memiliki rasa ingin tahu, percaya diri, dan keterkaitan pada Matematika serta memiliki rasa percaya pada daya dan kegunaan Matematika yang terbentuk melalui pengalaman belajar", dan KD 2.3 "Memiliki sikap terbuka, santun, objektif, menghargai pendapat dan karya 
teman dalam interaksi kelompok maupun aktivvitas sehari-hari”. Untuk kelima Bab pada buku teks siswa ini sudah memenuhi semua Kompetensi Inti dan Kompetensi Dasar 2 melalui berbagai Instruksi-intruksi yang ada pada buku teks pelajaran Matematika kelas VII semester 2.

Seperti halnya implementasi dari Kompetensi 2.1 terlihat dari Instruksi Ayo Kita Amati dan Ayo Kita Menanya yang akan membuat peserta didik memiliki sikap logis dan kritis. Sedangkan Instruksi Ayo Kita Menggali informasi dan Ayo Kita Menalar membuat peserta didik memiliki sikap analitik, konsisten, dan teliti. Selain itu disediakan banyak sekali latian soal pada Instruksi Ayo Kita Menalar dan Ayo Kita Berlatih sehingga diharapkan peserta didik bertanggung jawab, rensponsive, dan tidak mudah menyerah dalam memecahkan masalah. Hampir semua bab dari Bab 5 hingga Bab 9 memiliki instruksi-instruksi yang dijelaskan tadi sehingga dapat disimpulkan bahwa buku teks siswa matematika ini kelas VII semester 2 ini sudah memenuhi Kompetensi Dasar 2.1.

Untuk impelementasi kesesuaian buku teks mata pelajaran Matematika kelas VII semester 2 dengan implementasi dari Kompetensi 2.2 dapat dilihat dari Instruksi Ayo Kita Manalar dan Ayo Kita Berlatih yang ada pada semua Bab pada buku sehingga dapat memunculkan rasa ingin tahu, percaya diri, dan keterkaitan pada Matematika. Bukan hanya itu tetapi dijelaskannya dan dijabarkan kegunaan matematika pada setiap Bab mulai dari Bab 5 (Perbandingan), Bab 6 (Aritmetika Sosial), Bab 7 (Garis dan Sudut), Bab 8 (Segiempat dan Segitiga), dan Bab 9 (Penyajian data) membuat peserta didik memiliki rasa percaya pada daya dan kegunaan Matematika yang terbentuk melalui pengalaman belajar.Dari penjabaran dapat ditarik kesimpulan bahwa semua Bab dalam buku teks mata pelajaran Matematika Kelas VII semester 2 sudah memenuhi Kompetensi Dasar 2.2.

Selain Kompetensi Dasar 2.1 dan 2.2, didalam Kompetensi Inti 2 juga terdapat Kompetensi Dasar 2.3 yaitu "Memiliki sikap terbuka, santun, objektif, menghargai pendapat dan karya teman dalam interaksi kelompok maupun aktivitas sehari-hari". Didalam buku teks mata pelajaran Matematika kelas VII semester 2 sudah terdapat implementasi dari KD 2.3 hal ini dibuktikan dengan adanya Instruksi Ayo Kita Berbagi. Biasanya Instruksi Ayo Kita Berbagi muncul setelah terdapat Instruksi Ayo Kita Menalar dan Ayo Kita Berlatih. Hal tersebut dikarenakan Instruksi Ayo Kita Berbagi biasanya peserta didik menyajikan hasil pekerjaan dari latian soal yang ada pada Instruksi Ayo Kita Menalar atau Ayo Kita Berlatih didepan kelas. Kemudian peserta didik yang lain dapat memeriksa dan memberikan komentar secara santun dari penjelasan dan pendapat peserta didik yang mendapat giliran maju kedepan. Instruksi Ayo Kita Berbagi selalu ada disetiap Bab dalam buku teks pelajaran Matematika ini, mulai dari Bab 5 sampai Bab 9. Dari penjelasan tadi melalui Instruksi Ayo Kita Berbagi peserta didik memiliki sikap terbuka, santun, objektif, menghargai pendapat dan karya teman dalam interaksi kelompok maupun aktivitas sehari - hari.

Kompetensi Inti yang selanjutnya adalah Kompetensi Inti 3 atau Kompetensi Inti yang terfokus dalam Dimensi Pengetahuan. Isi dari Kompetensi Inti 3 sendiri adalah Memahami pengetahuan (faktual, konseptual, dan prosedural) berdasarkan rasa ingin tahunya tentang ilmu pengetahuan, teknologi, seni, budaya terkait fenomena dan kejadian tampak mata. Kompetensi Inti terdiri dari beberapa Kompetensi Dasar. Kompetensi Dasar pada Dimensi ini berbeda - beda tergantung dari Materi setiap Bab dalam Pelajaran Matematika kelas VII semester 2. Seperti Kompetensi Dasar 3.7 dan Kompetensi Dasar 3.8 menyinggung tentang kompetensi yang harus ada pada Bab 5 (Perbandingan). Isi dari Kompotensi Dasar 3.7 adalah Menjelaskan rasio dua besaran (satuannya sama dan berbeda). Sedangkan isi dari Kompetensi Dasar 3.8 adalah Membedakan perbandingan senilai dan berbalik nilai dengan menggunakan tabel data, grafik, dan persamaan. Setelah diteliti ternyata pada Bab 5 sudah memenuhi implementasi dari KD 3.7 dan 
KD 3.8. Kompetensi Dasar selanjutnya adalah Kompetensi Dasar 3.9 yang berhubungan dengan Materi Bab 6 (Aritmetika Sosial). Isi dari KD 3.9 adalah Mengenal dan menganalisis berbagai situasi terkait aritmatika sosial (penjualan, pembelian, potongan, keuntungan, kerugian, bunga tunggal, persentase, bruto, neto, tara). Tetapi didalam Bab 6 (Aritmetika Sosial) ternyata belum terpenuhi semua implementasi dari KD 3.9. Dalam Bab 6 Penjualan dan Pembelian tidak dijelaskan secara mendetail, hanya sebagai pengantar untuk masuk kedalam Materi Keuntungan dan Kerugian. Sedangkan Kompetensi Dasar dari Kompetensi Inti 3 lainnya sudah sesuai dengan materi yang ada Buku Teks Pelajaran Matematika kelas VII semester 2. Seperti halnya KD 3.10 yang berisi Menganalisis hubungan antar sudut sebagai akibat dari dua garis sejajar yang dipotong oleh garis transversal sudah terimplementasi semua dalam Bab 7 (Garis dan Sudut). KD 3.11 yang berisi Mengaitkan rumus keliling dan luas untuk berbagai jenis segiempat (persegi, persegipanjang, belahketupat, jajargenjang, trapezium, dan layang-layang) dan segitiga sudah dijelaskan dalam Bab 8 (Segiempat dan Segitiga). Dan yang terakhir adalah KD 3.12 yaitu Kompetensi Menganalisis hubungan antara data dengan cara penyajiannya (tabel, diagram garis, diagram batang, dan diagram lingkaran) sudah dijelaskan semuanya dalam Bab 9 (Penyajian Data).

Kalau tadi membahas tentang Kompetensi Inti 3 tentang Dimensi Pengetahuan. Selanjutnya akan dibahas tentang Kompetensi Inti 4 Dimensi Ketrampilan. Isi dari Kompetensi Dasar 4 sendiri adalah Mencoba, mengolah, dan menyaji dalam ranah konkret (menggunakan, mengurai, merangkai, memodifikasi, dan membuat) dan ranah abstrak (menulis, membaca, menghitung, menggambar, dan mengarang) sesuai dengan yang dipelajari di sekolah dan sumber lain yang sama dalam sudut pandang/teori. Jadi disini akan dijelaskan tentang isi buku teks mata pelajaran Matematika kelas VII semester 2 edisi Revisi 2017 terbitan Kemendikbud dengan tingkat kesesuaian dari implementasi Kompetensi Inti 4 (Dimensi Ketrampilan). Kompetensi Dasar dari Kompetensi Inti 4 sendiri berbeda-beda tergantung berdasarkan dengan materi dari Bab-Bab yang ada pada Buku. Seperti KD 4.7 tentang Menyelesaikan masalah yang berkaitan dengan rasio dua besaran (satuannya sama dan berbeda) dan KD 4.8 tentang Menyelesaikan masalah yang berkaitan dengan perbandingan senilai dan berbalik nilai, kedua kompetensi dasar ditujukan untuk Bab 5 (Perbandingan). KD lainnya adalah KD 4.9 tentang Menyelesaikan masalah berkaitan dengan aritmetika sosial (penjualan, pembelian, potongan, keuntungan, kerugian, bunga tunggal, persentase, bruto, neto, tara), KD tersebut adalah Kompetensi Dasar yang harus ada pada Bab 6 (Aritmatika Sosial). Ada juga KD 4.10 yaitu Kompetensi Dasar yang menyangkut dengan Materi dalam Bab 7 (Garis dan Sudut). Untuk isi kompetensi 4.10 sendiri adalah Menyelesaikan masalah yang berkaitan dengan hubungan antar sudut sebagai akibat dari dua garis sejajar yang dipotong oleh garis Transversal. Kompetensi Dasar lainnya yaitu KD 4.11 tentang Menyelesaikan masalah kontekstual yang berkaitan dengan luas dan keliling segiempat (persegi, persegipanjang, belahketupat, jajargenjang, trapesium, dan layang-layang) dan segitiga. KD 4.11 adalah Kompetensi Dasar yang sebaiknya termuat dalam Bab 8 (Segiempat dan Segitiga). Dan Kompetensi Dasar yang terakhir adalah KD 4.12 yaitu Menyajikan dan menafsirkan data dalam bentuk tabel, diagram garis, diagram batang, dan diagram Lingkaran yang berhubungan dengan. Dari penjabaran isi dari Kompetensi Dasar 4.12 diketahui bahwa KD tersebut berhubungan dengan Materi Bab 9 (Penyajian Data). Sebagian besar Kompetensi Dasar dari Kompetensi Inti 4 sudah terpenuhi semua pada Bab-bab pada Buku Pelajaran Matematika kelas VII semester 2 Edisi Revisi 2017, tetapi 
pada Bab 6 (Aritmetika Sosial) belum terpenuhi semuanya karena pada Bab tersebut belum sepenuhnya terbahas dalam implemetasi KD 4.9 seperti permasalahan penjualan dan pembelian masih sangat kurang dalam Bab 6.

\section{Hasil Penskoran}

Hasil Penskoran adalah hasil analisis terhadap persentase kesesuaian Kompetensi Inti dan Kompetensi Dasar yang akan dipaparkan pada Tabel 3 berikut ini.

Tabel 3. Hasil Penskoran Aspek Kesesuaian Materi dengan KI dan KD

\begin{tabular}{|c|c|c|c|c|c|c|}
\hline \multirow[b]{2}{*}{ KI } & \multirow[b]{2}{*}{$\mathrm{KD}$} & \multirow[b]{2}{*}{$\begin{array}{c}\text { Halaman dalam } \\
\text { Buku }\end{array}$} & \multicolumn{3}{|c|}{ Hasil analisis } & \multirow[b]{2}{*}{$\begin{array}{c}\% \\
\text { Kesesuaian }\end{array}$} \\
\hline & & & $\begin{array}{c}\text { Tidak } \\
\text { Terpenuhi } \\
\text { (1) }\end{array}$ & $\begin{array}{l}\text { Terpenuhi } \\
\text { Sebagian } \\
\text { (3) }\end{array}$ & $\begin{array}{c}\text { Terpenuhi } \\
\text { (5) }\end{array}$ & \\
\hline KI 1 & $\begin{array}{l}\text { KD } 1.1 \\
\text { BAB } 5 \\
\text { BAB } 6 \\
\text { BAB } 7 \\
\text { BAB } 8 \\
\text { BAB } 9\end{array}$ & $\begin{array}{l}1-66 \\
67-105 \\
106-184 \\
185-302 \\
303-376\end{array}$ & 1 & $\begin{array}{l}3 \\
3 \\
3\end{array}$ & 5 & $\begin{array}{c}\frac{15}{25} \times 100 \\
\quad=60 \%\end{array}$ \\
\hline \multirow{3}{*}{ KI 2} & $\begin{array}{l}\text { KD } 2.1 \\
\text { BAB } 5 \\
\text { BAB } 6 \\
\text { BAB } 7 \\
\text { BAB } 8 \\
\text { BAB } 9\end{array}$ & $\begin{array}{l}1-66 \\
67-105 \\
106-184 \\
185-302 \\
303-376\end{array}$ & & & $\begin{array}{l}5 \\
5 \\
5 \\
5 \\
5\end{array}$ & $\begin{array}{l}\frac{25}{25} \times 100 \\
=100 \%\end{array}$ \\
\hline & $\begin{array}{l}\text { KD } 2.2 \\
\text { BAB } 5 \\
\text { BAB } 6 \\
\text { BAB } 7 \\
\text { BAB } 8 \\
\text { BAB } 9\end{array}$ & $\begin{array}{l}1-66 \\
67-105 \\
106-184 \\
185-302 \\
303-376\end{array}$ & & & $\begin{array}{l}5 \\
5 \\
5 \\
5 \\
5 \\
\end{array}$ & $\begin{array}{l}\frac{25}{25} \times 100 \\
=100 \%\end{array}$ \\
\hline & $\begin{array}{l}\text { KD } 2.3 \\
\text { BAB } 5 \\
\text { BAB } 6 \\
\text { BAB } 7 \\
\text { BAB } 8 \\
\text { BAB } 9\end{array}$ & $\begin{array}{l}1-66 \\
67-105 \\
106-184 \\
185-302 \\
303-376\end{array}$ & & & $\begin{array}{l}5 \\
5 \\
5 \\
5 \\
5\end{array}$ & $\begin{array}{l}\frac{25}{25} \times 100 \\
=100 \%\end{array}$ \\
\hline \multirow{6}{*}{ KI 3} & KD 3.7 & $1-66$ & & & 5 & \multirow{6}{*}{$\begin{array}{l}\frac{28}{30} \times 100 \\
=93 \%\end{array}$} \\
\hline & KD 3.8 & $1-66$ & & & 5 & \\
\hline & KD 3.9 & $67-105$ & & 3 & & \\
\hline & KD 3.10 & $106-184$ & & & 5 & \\
\hline & KD 3.11 & $185-302$ & & & 5 & \\
\hline & KD 3.12 & $303-376$ & & & 5 & \\
\hline \multirow{3}{*}{ KD 4} & KD 4.7 & $1-66$ & & & 5 & \multirow{3}{*}{$\begin{array}{l}\frac{28}{30} \times 100 \\
=93 \%\end{array}$} \\
\hline & KD 4.8 & $1-66$ & & & 5 & \\
\hline & KD 4.9 & $67-105$ & & 3 & & \\
\hline
\end{tabular}




\begin{tabular}{|c|c|c|c|c|c|c|}
\hline \multirow{5}{*}{$\mathrm{KI}$} & \multirow[b]{2}{*}{$\mathrm{KD}$} & \multirow[b]{2}{*}{$\begin{array}{c}\text { Halaman dalam } \\
\text { Buku }\end{array}$} & \multicolumn{3}{|c|}{ Hasil analisis } & \multirow{5}{*}{$\begin{array}{c}\% \\
\text { Kesesuaian }\end{array}$} \\
\hline & & & $\begin{array}{c}\text { Tidak } \\
\text { Terpenuhi } \\
\text { (1) }\end{array}$ & $\begin{array}{l}\text { Terpenuhi } \\
\text { Sebagian } \\
\text { (3) }\end{array}$ & $\begin{array}{c}\text { Terpenuhi } \\
\text { (5) }\end{array}$ & \\
\hline & $\mathrm{KD} 4.10$ & $106-184$ & & & 5 & \\
\hline & $\mathrm{KD} 4.11$ & $185-302$ & & & 5 & \\
\hline & KD 4.12 & $303-376$ & & & 5 & \\
\hline \multicolumn{6}{|c|}{ Presentase Keseluruhan KI dan KD } & $86.5 \%$ \\
\hline
\end{tabular}

\section{SIMPULAN}

Berdasarkan hasil penelitian dan pembahasan yang telah diuraikan dalam bab IV, dapat disimpulkan bahwa buku yang berjudul Matematika SMP/MTs KELAS VII SEMESTER 2 Edisi Revisi 2017 yang diterbitkan oleh Kementrian Pendidikan dan Kebudayaan dalam implementasi Kurikulum 2013 sudah memenuhi standar buku teks dengan perolehan skor 86,5\% (kategori "sangat baik"). Hal ini ditunjukkan dengan hasil perolehan skor pada masing-masing aspek analisis buku siswa. Tingkat kesesuaian materi buku teks mata pelajaran Matematika SMP/MTs Kelas VII Kurikulum 2013 Edisi Revisi 2017 dengan Kompetensi Dasar (KD) dari Kompetensi Inti (KI)-1 diperoleh skor $60 \%$ (Cukup Baik). Tingkat kesesuaian materi buku teks mata pelajaran Matematika SMP/MTs Kelas VII Kurikulum 2013 Edisi Revisi 2017 dengan Kompetensi Dasar (KD) dari Kompetensi Inti (KI)-2 diperoleh skor 100\% (Sangat Baik). Tingkat kesesuaian materi buku teks mata pelajaran Matematika SMP/MTs Kelas VII Kurikulum 2013 Edisi Revisi 2017 dengan Kompetensi Dasar (KD) dari Kompetensi Inti (KI)-3 diperoleh skor 93\% (Sangat Baik). Tingkat kesesuaian materi buku teks mata pelajaran Matematika SMP/MTs Kelas VII Kurikulum 2013 Edisi Revisi 2017 dengan Kompetensi Dasar (KD) dari Kompetensi Inti (KI)-4 diperoleh skor 93\% (Sangat Baik).

\section{DAFTAR PUSTAKA}

Akbar, Sa'dun. 2013. Instrumen Perangkat Pembelajaran. Bandung: PT Remaja Rosdakarya Arikunto, Suharsimi. 2010. Prosedur Penelitian: Suatu Pendekatan Praktis. Jakarta: Rineka Cipta

As'ari, Abdur Rahman, Mohammad Tohir, Erik Valentino, Zainul Imron, dan Ibnu Taufiq. 2017a.

Buku Guru Matematika SMP/MTs Kelas VII Edisi Revisi 2017.Jakarta: Kementrian Pendidikan dan Kebudayaan.

------. 2017b. Buku Matematika SMP/MTs Kelas VII Semester 2 Edisi Revisi 2017.Jakarta: Kementrian

Pendidikan dan Kebudayaan.

Danim, Sudarwan. 2010. Teknologi Pendidikan. Jakarta: Bumi Aksara.

Mulyasa, E. 2013. Pengembangan dan Implementasi Kurikulum 2013. Bandung: PT Remaja Rosdakarya. Haryono, Didi (Ed.). 2014. FILSAFAT MATEMATIKA Suatu Tinjanan Epistemologi dan Filosofis. Bandung: Alfabeta. 
Hidayat, Sholeh. (2013). Pengembangan Kurikulum Baru. Bandung: PT Remaja Rosdakarya

Jarnawi, Afgani Dahlan, 2014. Analisis Kurikulum Matematika. Volume 1, Issue 515. Universitas Terbuka

Kementriaan Agaman RI. 2014. Sejarah Kebudayaan Islam untuk Madrasah Tsanawiyah Kelas VII. Jakarta: Kementrian Agama.

Macintyre T. \& Hamilton, S. 2010. Mathematics learner and Mathematics text book: A question of identity ? Whose curriculum ? Whose Mathematics?. The Curriculum Journal. 21(1), 3-23

Mera, V \& Griffths, B. 2012. Textbooks mediation of teaching: An example from tertiary mathematics instrutors. Education Study Mathematics. 79, 85-107

Moeleng, Lexy J. 2017. Metodologi; Penelitian Kualitatif. Bandung: PT Remaja Rosdakarya.

Munir. 2008. Kurikulum Berbasis Teknologi Informasi dan Komunikasi. Bandung: Alfabeta

Musfah, Jejen. 2012. Peningkatan Kompetensi Guru Melalaui Pelatiban dan Sumber belajar. Jakarta:

Prenamedia.

Nasution. 2012. Teknologi Pendidikan. Jakarta: Bumi Aksara.

Prastowo, Andi. 2015. Asesmen Pembelajaran SD. Jakarta: Departemen Pendidikan Nasional.

Peraturan Menteri Pendidikan dan Kebudayaan Nomor 21 Tahun 2016 tentang Standar Isi Pendidikan Dasar dan Menengah.

Peraturan Menteri Pendidikan dan Kebudayaan Nomor 20 Tahun 2016 tentang Standar Kompetensi Lulusan Pendidikan Dasar dan Menengah.

Permendikbud RI Nomor 37 Tahun 2018 tentang Perubahan Atas Peraturan Menteri Pendidikan dan Kebudayaan Nomor 24 Tahun 2016 tentang Kompetensi Inti dan Kompetensi Dasar Pelajaran Pada Kurikulum 2013 pada Pendidikan Dasar dan Menengah.

Peraturan Pemerintah No. 32 Tahun 2013 tentang Perubahan Standar Nasional Pendidikan.

Ramda. Apolonia Hendric. 2017. Analsis Kesesuaian Materi pada Buku Teks Matematika Kelas VII dengan Kurikulum 2013,Phytagoras: Jurnal Pendidikan Matematika. (Online), Vol. 12 No.1, (http://jurnal.uny.ac.id/indexs.php/phytagoras, diakses pada 15 April 2020)

Satori, Djam'an dan Aan Komariah. 2013. Metodologu Penelitian Kualitatif. Bandung : Alfabeta. Sugiyono. 2016. Metode Penelitian Kuantitatif, Kualitatif, dan RnD. Bandung: Alfabeta

Suharsono dan Ana Retnoningsih. 2013. Kamus Besar Bahasa Indonesia. Semarang: Widya Karya.

Supardi. 2013. Publikasi Imiah Non Penelitian dan karya Inovatif. Yogyakarta: Andi Offset.

Susilana, Rudi (Koordinator). 2006. Kurikulum dan Pembelajaran. Bandung: FIP UPI Bandung.

Tafsir, Ahmad. 2006. Filsafat Pendidikan Islam.Bandung: Remaja Rosda Karya.

Tamara, Awi. 2018. Analisis Kesesuaian Materi Ajar Dengan Kompetensi Inti dan Kompetensi Dasar Kurikulum 2013. Skripsi tidak diterbitkan. Lampung: UIN Raden Intan Lampung. 
Tarigan, H. G \& Tarigan, D. 2009. Telaah Buku Teks Bahasa IndonesiaI. Bandung: Angkasa.

Unam, Saida. 2017. Analisis Kesesuaian Materi Buku Teks Mata Pelajaran Matematika SD Kelas 3 Terhadap Standar Isi. Skripsi tidak diterbitkan. Semarang: Universitas Negeri Semarang. Undang-undang No. 20 Tahun 2003 Bab 1 Pasal 1 Ayat 1 tentang Sistem Pendidikan Nasional. Undang-undang No. 20 Tahun 2003 Pasal 3 tentang Tujuan Pendidikan Nasional.

Undang-undang No. 20 Tahun 2003 Bab 1 Pasal 1 Ayat 19 tentang Pengertian Kurikulum.

Waybin, Eusabia Florenzia. 2014. Implementasi Kurikulum 2013 Dalam Proses Pembelajaran Di SMK Negeri 3 Yogyakarta. Skripsi tidak diterbitkan. Yogyakarta : Universitas Negeri Yogyakarta. Yusmium, Ika. 2015. Analisis Buku Teks Mata Pelajaran Ilmu Pengetabuan Alam SMP/MTs Kurikulum 2013. Skripsi tidak diterbitkan. Semarang: UIN Walisongo.

Zed, Mestika. 2008. Metode Penelitian Kepustakaan . Jakarta: Yayasan Obor Indonesia. 